\title{
ТЕРМОХРОМНІ ВЛАСТИВОСТІ ПЛІВОК ОКСИДУ ВАНАДІЮ, ОТРИМАНИХ МАГНЕТРОННИМ НАПИЛЕННЯМ
}

\author{
В.П. МЕЛЬНИК, І.М. ХАЦЕВИЧ, Ю.В. ГОЛТВЯНСЬКИЙ, В.А. НІКІРІН, \\ Б.М. РОМАНЮК, В.Г. ПОПОВ, В.П. КЛАДЬКО, А.В. КУЧУК
}

УДК 621.315.592.4 (c) 2011

Інститут фізики напівпровідників ім. В.Є. Лашкарьова НАН України

(Просn. Науки, 45, Kü̈в 03028; e-mail: romb@isp. kiev. ua)

\begin{abstract}
Досліджено структурні, електрофізичні та оптичні властивості термохромних плівок $\mathrm{VO}_{2}$, отриманих магнетронним напиленням. Продемонстровано можливість поліпшення термохромних властивостей плівок $\mathrm{VO}_{2}$ при їх двостадійному формуванні: напиленні при температурі підкладки $200{ }^{\circ} \mathrm{C}$ і подальшим термічними відпалом. Дані експериментальних досліджень підтверджують формування в досліджуваних плівках кристалітів діоксиду ванадію з середнім розміром 26 нм та моноклінною кристалічною граткою. При фазовому переході зміна провідності плівок досягає трьох порядків, а оптичне пропускання змінюється (при довжині хвилі зондуючого світла $\lambda=2$ мкм) у 16 разів. Показано, що зміна параметрів відпалу синтезованих плівок дозволяє варіювати термохромні властивості плівок. Отримані результати пояснюються в межах моделі формування нановключень кристалічної фази $\mathrm{VO}_{2}$.
\end{abstract}

\section{1. Вступ}

Синтез термо- та електрохромних тонких плівок, в яких оптичне пропускання матеріалу можна суттево змінювати за рахунок зміни температури чи електричного поля є актуальною задачею у зв'язку з розвитком енергозберігаючих технологій. Діоксид ванадію, завдяки існуванню зворотного переходу з напівпровідникової фази в металічну при температурі $T_{t} \approx 68{ }^{\circ} \mathrm{C}$, вважається одним із найперспективніших матеріалів для термохромних покриттів [1, 2]. Фазовий перехід пов'язаний із трансформацією кристалічної гратки з моноклінної структури (в цьому стані діоксид ванадію є вузькозонним напівпровідником 3 шириною забороненої зони $\left.E_{g}=0,7 \mathrm{eB}\right)$ в тетрагональну при температурах, вищих за $T_{t}$, коли валентна зона та зона провідності $\mathrm{VO}_{2}$ перекриваються, i матеріал проявляє металічні властивості [4-6]. Така трансформація кристалічної гратки відбувається за час $\sim 500$ фс $[6,7]$ при зміні температури зразка менше ніж на $0,1^{\circ} \mathrm{C}[8]$. Такий різкий перехід зумовлює зміну питомого опору $\mathrm{VO}_{2}$ на 5 порядків [3] та зміну пропускання світла в інфрачервоній області $(2-$ 4,5 мкм) в 1000 разів [4]. Можливість такої швидкої трансформації з напівпровідникового стану в металічний пов'язана з тим, що при фазовому переході спостерігається дуже мала зміна об'єму кристала $\mathrm{VO}_{2}$ : $\sim 0,044 \%$ [6].

Проблемою синтезу термохромних плівок на основі ванадію є можливість одночасного утворення нетермохромних оксидів ванадію ( $\mathrm{VO}, \mathrm{V}_{2} \mathrm{O}_{3}, \mathrm{~V}_{2} \mathrm{O}_{5}$ ), що суттєво ускладнює оптимізацію процесу напилення [8].

Магнетронне напилення стехіометричних термохромних плівок діоксиду ванадію зазвичай проводять на нагріту підкладку $\left(\sim 400-500{ }^{\circ} \mathrm{C}\right)$ при дуже точному контролі концентрації кисню та інших параметрів нанесення з метою мінімізації вмісту нетермохромних оксидів у плівці. Для таких плівок спостерігається фазовий перехід без додаткових термообробок $[1,2,5$, $6,9]$. Нанесення плівок на підкладку з температурою $<400{ }^{\circ} \mathrm{C}$ не дозволяє отримати термохромні плівки діоксиду ванадію. Лише подальші термічні відпали в певних режимах приводять до появи термохромних властивостей плівок $[7,11]$.

Актуальною залишається задача зниження температури фазового переходу для плівок $\mathrm{VO}_{2}$ та поліпшення їх оптичних параметрів: більшість запропонованих методів (введення домішок W [12], Nb, Mo, Li [10], імплантація кисню [4]) разом зі зниженням 


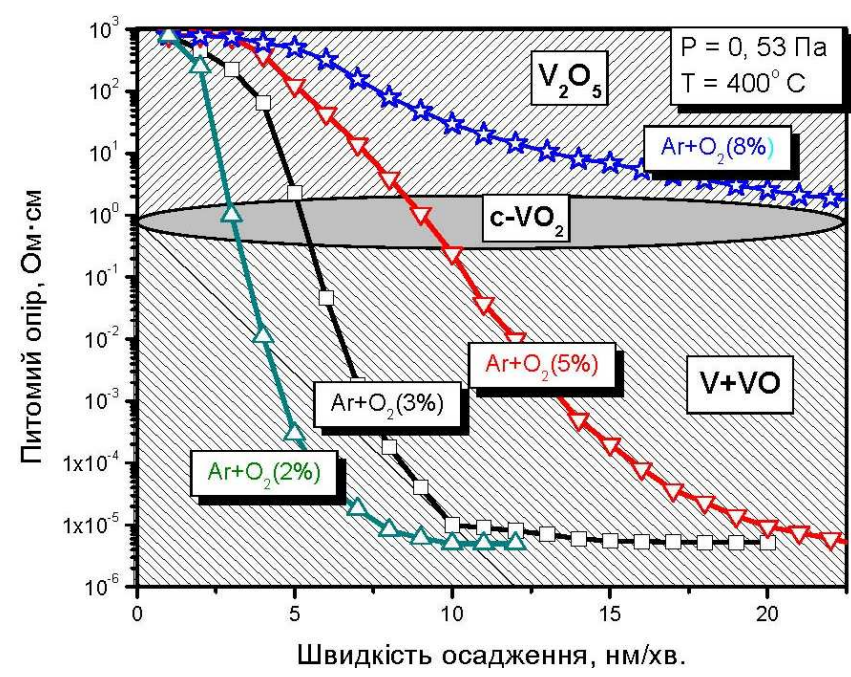

Рис. 1. Залежність питомого опору отриманих плівок оксиду ванадію від швидкості осадження при різній концентрації кисню в суміші

температури $T_{t}$ приводять до зменшення змін питомого опору та оптичного пропускання.

Метою даної роботи було поліпшення термохромних (електричних та оптичних) властивостей синтезованих плівок $\mathrm{VO}_{2}$ при їх двостадійному формуванні: магнетронному напиленні при температурі підкладки $T_{s}=200{ }^{\circ} \mathrm{C}$ і подальшому термічному відпалі в різних режимах.

\section{2. Методика експерименту}

Термохромні плівки $\mathrm{VO}_{2}$ осаджували методом магнетронного напилення в установці ВУП-5М з планарним магнетроном шляхом розпорошення ванадієвої мішені (чистотою 99,7\%). Перед нанесенням плівки камеру відкачували до вакууму $\sim 3 \cdot 10^{-4}$ Па. Для формування плазми використовували суміш Ar з прецизійно контрольованою часткою $\mathrm{O}_{2}$ (від 2 до 10 об'ємних \%). Тиск у камері у процесі напилення підтримували постійним (від 11 до 0,4 Па). Плівки осаджували на кремнієві пластини та кварцове скло при температурах $200{ }^{\circ} \mathrm{C}$ та $400{ }^{\circ} \mathrm{C}$. Після напилення зразки охолоджували у робочій камері при тиску $\sim 0,2$ Па до кімнатної температури. Частину отриманих зразків піддавали термічним відпалам на повітрі або в $\mathrm{H}_{2}$ при температурах $T=200-400{ }^{\circ} \mathrm{C}$, тривалістю $10-$ $60 \mathrm{xB}$.

На досліджуваних зразках проводили вимірювання питомого опору $\rho$ та оптичного пропускання в діапазоні температур від 20 до $105{ }^{\circ} \mathrm{C}$. Структурні властивості зразків аналізували методом рентгенівської дифракції. Товщину плівок визначали за допомогою профілометра.

\section{3. Результати експериментів}

На рис. 1 наведено залежності питомого опору плівок оксиду ванадію від швидкості осадження для різних значень концентрації кисню в суміші при тиску 0,53 Па та температурі підкладки $400{ }^{\circ} \mathrm{C}$. Вимірювання питомого опору проводили за кімнатної температури. При концентраціях кисню в суміші 2-3\% плівки діоксиду ванадію вдається отримати тільки при низьких швидкостях напилення. У цих режимах незначна зміна швидкості осадження приводить до суттєвої зміни опору плівок. При концентраціях $\mathrm{O}_{2}$ в суміші більше $8 \%$ отримуються високоомні плівки, опір яких слабо зменшується зі зміною швидкості осадження. Такі плівки мають світло-жовте забарвлення, а їх склад відповідає складу $\mathrm{V}_{2} \mathrm{O}_{5}$.

При швидкостях осадження більше 15 нм/хв в суміші з концентрацією кисню 3-6\% осаджуються провідні плівки з включеннями чистого ванадію.

Таким чином, зміна технологічних параметрів процесу напилення (відсоток $\mathrm{O}_{2}$ в суміші, тиск у камері, потужність розряду магнетрона та температуру підкладки) приводила, з одного боку, до зміни швидкості осадження плівок, з іншого - до зміни їх питомого опору, і дозволяла отримувати плівки різного стехіометричного складу: від чистого ванадію до оксиду ванадію $\mathrm{V}_{2} \mathrm{O}_{5}$.

Отже, при режимі підігрітої підкладки для отримання плівок полікристалічного діоксиду ванадію, в яких спостерігається фазовий перехід, необхідно дуже прецизійно підібрати технологічні параметри напилення, щоб, з одного боку, забезпечити стехіометричний склад $\mathrm{VO}_{2}$, а з іншого боку, створити умови для формування саме кристалічної фази діоксиду ванадію (нагрів підкладки під час напилення до $T_{s} \geq 400{ }^{\circ} \mathrm{C}$ ). Виходячи з наведених даних, для отримання кристалічних плівок $\mathrm{VO}_{2}$ ми використовували напилення у суміші $\mathrm{Ar}+5 \% \mathrm{O}_{2}$ при швидкостях 10$12 \mathrm{HM} / \mathrm{xB}$.

Також синтезовано плівки при $T_{s}=200{ }^{\circ} \mathrm{C}$, в яких після додаткового відпалу при температурі $300{ }^{\circ} \mathrm{C}$ спостерігались термохромні властивості. Відпали цих плівок при температурах, менших від $300{ }^{\circ} \mathrm{C}$, на повітрі (до 60 хв) не впливали на термохромні властивості плівок, а відпали при температурах, вищих за $350{ }^{\circ} \mathrm{C}$ приводили до їх деградації.

На рис. 2 наведено залежності питомого опору плівок від температури при нагріві зразка (крива 1) та 

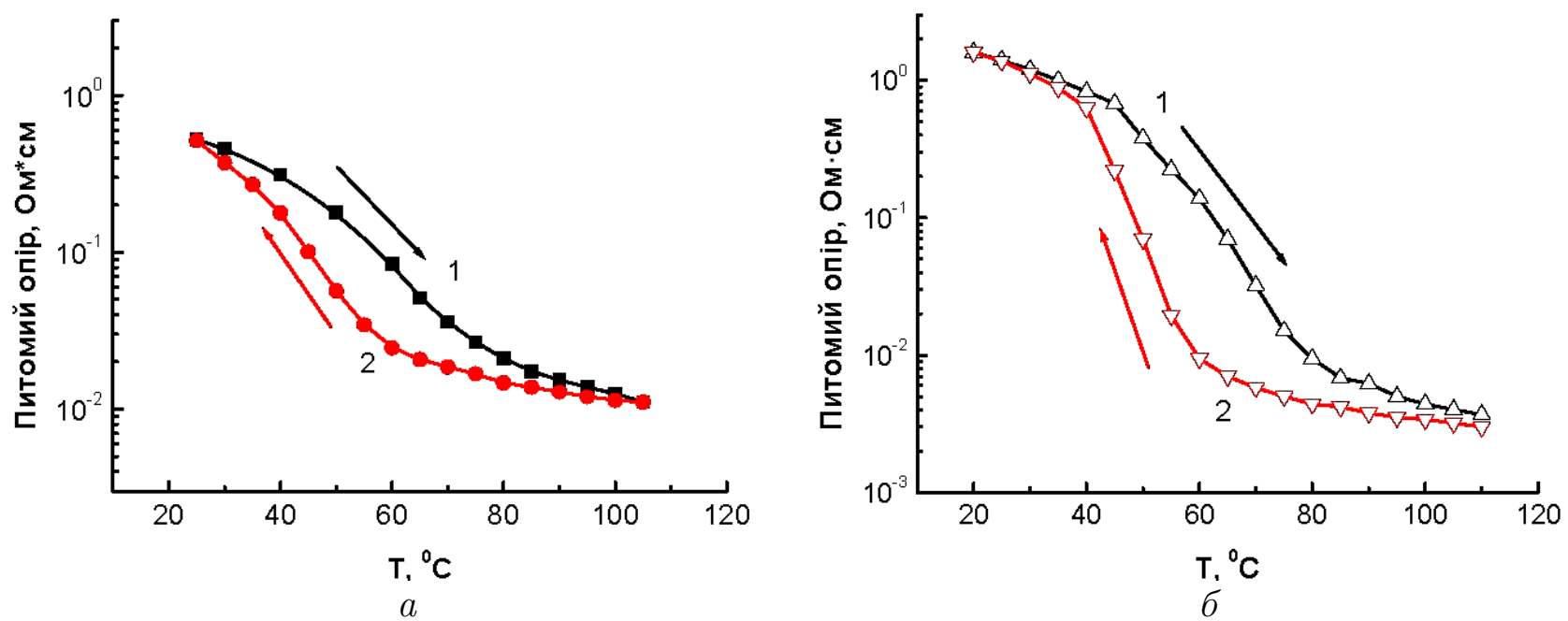

Рис. 2. Температурна залежність питомого опору отриманих плівок оксиду ванадію: для плівки, осадженої при $T_{s}=400{ }^{\circ} \mathrm{C}(a)$; для плівок, осаджених при $T_{s}=200{ }^{\circ} \mathrm{C}$ і відпалених при температурі $300{ }^{\circ} \mathrm{C}$ на повітрі впродовж 30 хв (б)

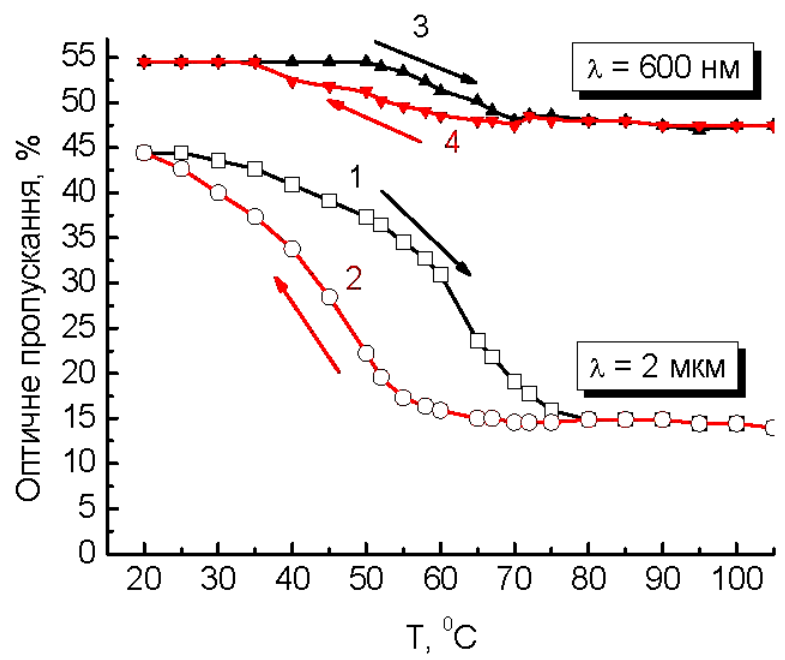

a

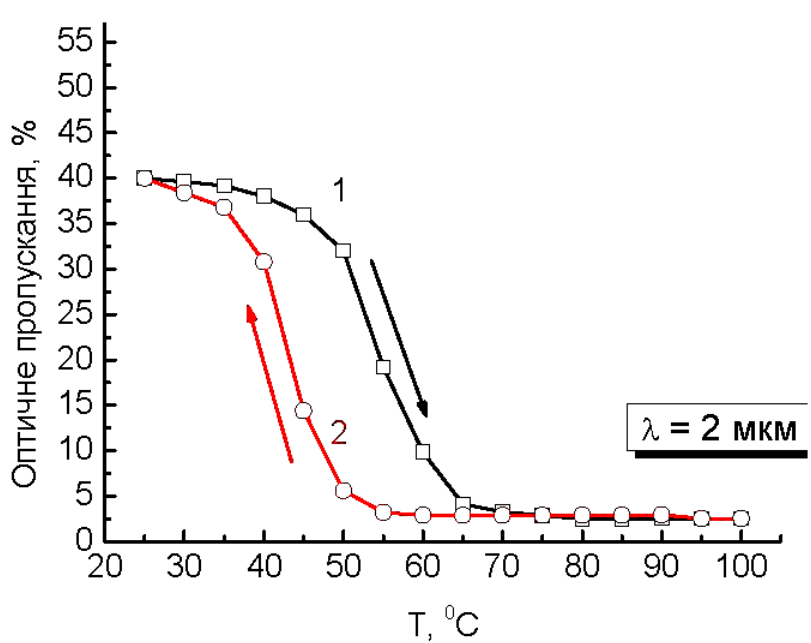

б

Рис. 3. Температурна залежність оптичного пропускання плівок оксиду ванадію: для плівки, осадженої при $\mathrm{T}_{s}=400{ }^{\circ} \mathrm{C}(a)$; для плівок, осаджених при $T_{s}=200{ }^{\circ} \mathrm{C}$ і відпалених при температурі $300{ }^{\circ} \mathrm{C}$ на повітрі впродовж 30 хв (б)

при його охолодженні (крива 2). Для плівок, отриманих напиленням на підкладку при $T_{s}=400{ }^{\circ} \mathrm{C}$, при нагріванні спостерігається нерізкий перехід з напівпровідникового стану в металічну фазу при температурі $\sim 62{ }^{\circ} \mathrm{C}$ (рис. $2, a$ ). При цьому питомий опір плівки зменшується майже на два порядки. Зворотний перехід при охолодженні плівки доволі розмитий і спостерігається при температурі $\sim 47^{\circ} \mathrm{C}$. Для плівок, отриманих напиленням на підкладку з $T_{s}=200{ }^{\circ} \mathrm{C}$ під час нагрівання спостерігається більш різкий перехід при температурі $\sim 68{ }^{\circ} \mathrm{C}$ (рис. $\left.2, \sigma\right)$. При цьому питомий опір плівки зменшується більше ніж удвічі.
Зворотний перехід при охолодженні плівки спостерігається при температурі $\sim 49{ }^{\circ} \mathrm{C}$.

На рис. 3 наведено температурні залежності оптичного пропускання плівок оксиду ванадію, отриманих при $T_{s}=400{ }^{\circ} \mathrm{C}$ та $T_{s}=200{ }^{\circ} \mathrm{C}$ з подальшою термічною обробкою (криві 1, 3 - нагрів; криві 2, 4 - охолодження). Для плівок $3 T_{s}=$ $400{ }^{\circ} \mathrm{C}$ при нагріванні спостерігали нерізкий перехід при температурі $\sim 63{ }^{\circ} \mathrm{C}$ (рис. 3,a, крива 1), пропускання світла в інфрачервоній області $(\lambda=2$ мкм $)$ зменшувалось $3 \quad 45 \%$ до $15 \%$ (рис. 3,a). При охолодженні зразків перехід спо- 


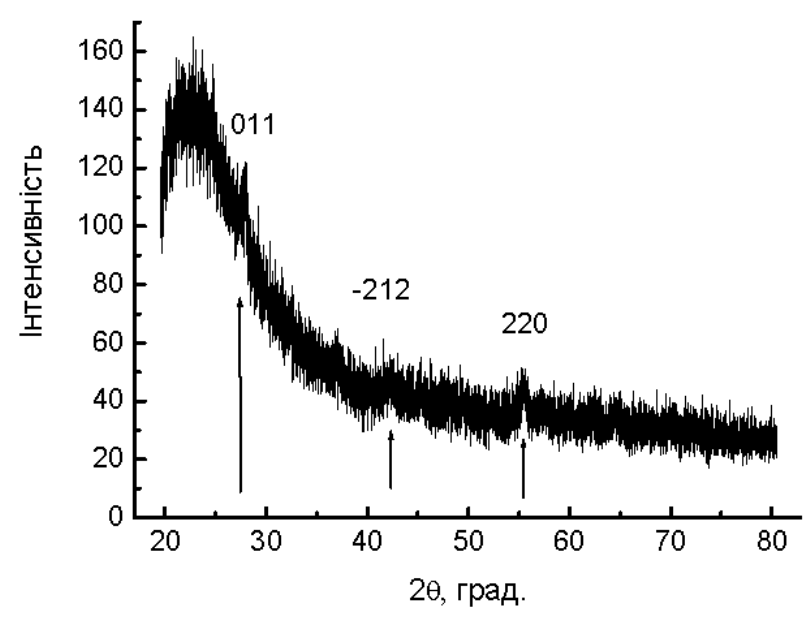

$a$

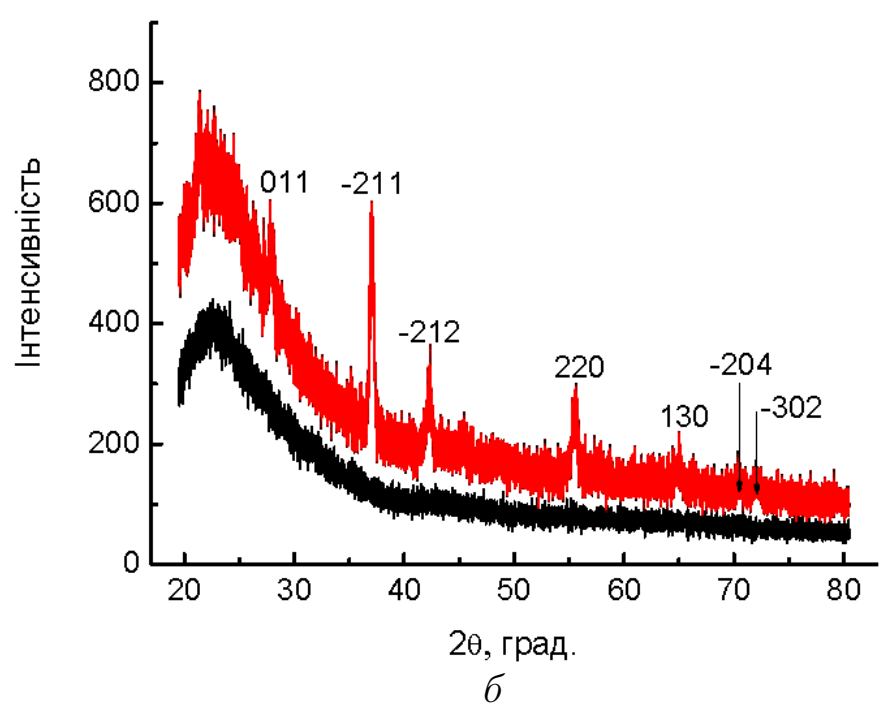

$\sigma$

Рис. 4. Дифракція $X$-променів на плівках оксиду ванадію: осадженої при $T_{s}=400{ }^{\circ} \mathrm{C}(a)$; для плівок, осаджених (нижня крива) при $T_{s}=200{ }^{\circ} \mathrm{C}$ і відпалених (верхня крива) при температурі $300{ }^{\circ} \mathrm{C}$ на повітрі впродовж 30 хв (б)

стерігали при температурі $\sim 49{ }^{\circ} \mathrm{C}$ (рис. 3,a, крива 2).

Для цих плівок спостерігали незначну зміну оптичного пропускання, і у видимій області спектра $(\lambda=$ 600 нм) - пропускання зменшувалося з $55 \%$ (при кімнатній температурі) до $48 \%$ (при температурах, більших за $\left.80{ }^{\circ} \mathrm{C}\right)$.

Для плівок $3 T_{s}=200{ }^{\circ} \mathrm{C}$, відпалених при $T=300{ }^{\circ} \mathrm{C}$, при нагріванні спостерігали більш суттєве i різке зменшення пропускання світла в інфрачервоній області $(\lambda=2$ мкм): від $40 \%$ до $2,5 \%$ (рис. $3, \sigma)$. Температура переходу $\sim 55^{\circ} \mathrm{C}$ виявилася більш як на $10{ }^{\circ} \mathrm{C}$ нижчою від температури, визначеної за зміною питомого опору. Зворотний перехід (при охолодженні) спостерігався при температурі $\sim 43{ }^{\circ} \mathrm{C}$. Оптичне пропускання у видимій області $(\lambda=600$ нм) при нагріві зразків другої серії практично не змінювалось і становило $\sim 25 \%$.

Незбігання в температурах переходу, отриманих 3 вимірювань питомого опору та оптичного пропускання, спостерігали і раніше в роботах $[13,14]$ і пояснювали впливом додаткового оптичного збудження при вимірах оптичного пропускання.

Дані дифракції рентгенівських променів на досліджуваних плівках оксиду ванадію підтверджують наявність у них кристалітів $\mathrm{VO}_{2}$ (рис. 4). Для плівок, напилених при $T_{s}=400{ }^{\circ} \mathrm{C}$, спостерігаються слабкі піки дифракції $X$-променів від трьох кристалографічних площин: (011), (212) та (220) кристалічної фази $\mathrm{VO}_{2}$ (рис. 4,a). Для плівок, напилених при $T_{s}=$ $200{ }^{\circ} \mathrm{C}$, на дебаєграмах відсутні піки дифракції $X$ - променів від кристалографічних площин (рис. 4,б, нижня крива). Після додаткової термічної обробки таких плівок спостерігаються чіткі піки дифракції $X$ променів від семи кристалографічних площин: (011), $(-211),(-212),(220),(130),(-204)$ та $(-302)$ (рис. $4, б$, верхня крива).

На рис. 5 показано температурну залежність питомого опору плівок оксиду ванадію після додаткових термічних відпалів у різних середовищах. Відпал на повітрі при температурі $300{ }^{\circ} \mathrm{C}$ (30 хв) приводить до збільшення питомого опору плівок оксиду ванадію, при цьому параметри переходу не змінюються (див. таблицю). Відпал плівок у водні при температуpi $350^{\circ} \mathrm{C}(30$ хв) приводить до зменшення їх питомого опору. При цьому спостерігається зміщення переходу в область менших температур (див. таблицю).

На вставці до рис. 5 наведено результат аналізу параметрів фазового переходу за першою похідною залежності питомого опору від температури при нагріванні, для зразка, напиленого на підкладку з $T_{s}=$ $400{ }^{\circ} \mathrm{C}$, після додаткового відпалу в атмосфері $\mathrm{H}_{2}$ $\left(350{ }^{\circ} \mathrm{C}, 30\right.$ хв). Згідно 3 методикою аналізу, описаною в [2], максимум похідної відповідає температуpi переходу, півширина кривої $\frac{d(\log (\rho(T)))}{d T}$ (ширина на половині висоти) характеризує швидкість переходу, а площа під кривою характеризує інтенсивність переходу, тобто показує на скільки порядків зменшується питомий опір плівки внаслідок переходу.

Було проаналізовано отримані залежності питомого опору від температури для зразків після нанесення та термічних обробок. Результати наведено у таблиці. 
Параметри фазового переходу синтезованих плівок $\mathrm{VO}_{2}$

\begin{tabular}{|c|c|c|c|c|c|}
\hline \multicolumn{2}{|c|}{ Плівка } & \multicolumn{2}{|c|}{ Температура переходу, ${ }^{\circ} \mathrm{C}$} & \multirow[t]{2}{*}{ Гістерезис, ${ }^{\circ} \mathrm{C}$} & \multirow{2}{*}{$\begin{array}{c}\text { Інтенсивність переходу } \\
\text { (порядків величини) }\end{array}$} \\
\hline Температура напилення & Термічні обробки & нагр. & охол. & & \\
\hline \multirow[t]{3}{*}{$200^{\circ} \mathrm{C}$} & - & - & - & - & - \\
\hline & $300{ }^{\circ} \mathrm{C}$ (повітря) & 68,0 & 49,1 & 19,6 & 2,7 \\
\hline & $350{ }^{\circ} \mathrm{C}$ (повітря) & 77,3 & 41,6 & 35,7 & 2,2 \\
\hline \multirow[t]{4}{*}{$400{ }^{\circ} \mathrm{C}$} & - & 62,0 & 46,6 & 15,4 & 1,7 \\
\hline & $300{ }^{\circ} \mathrm{C}$ (повітря) & 62,4 & 47,1 & 15,3 & 1,4 \\
\hline & $300{ }^{\circ} \mathrm{C}\left(\mathrm{H}_{2}\right)$ & 63,6 & 52,6 & 11,0 & 1,8 \\
\hline & $350{ }^{\circ} \mathrm{C}\left(\mathrm{H}_{2}\right)$ & 54,5 & 37,3 & 14,2 & 1,7 \\
\hline
\end{tabular}
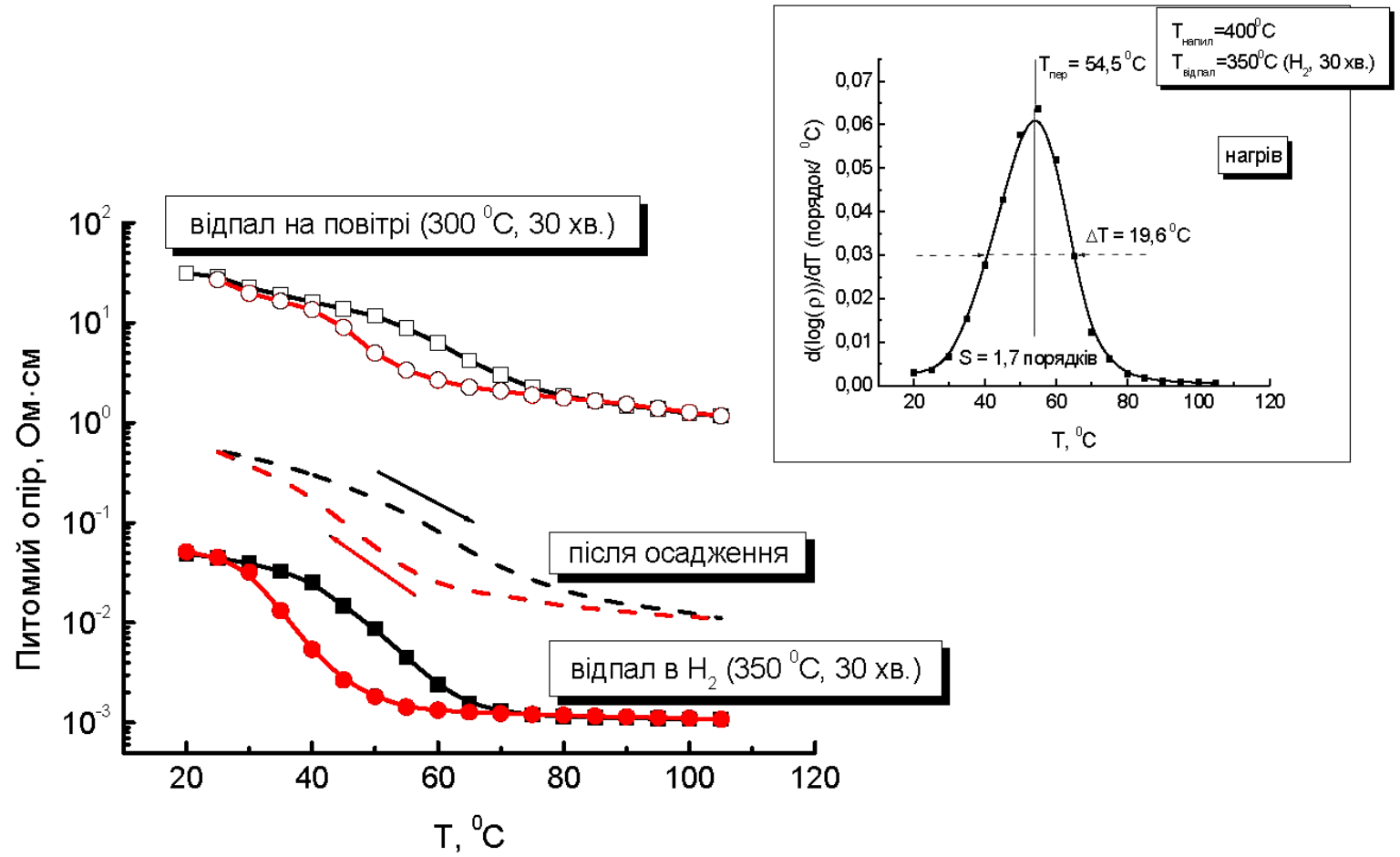

Рис. 5. Температурна залежність питомого опору плівки оксиду ванадію для різних умов відпалу. На вставці - приклад аналізу параметрів переходу згідно з [2]

Для плівок, осаджених при $T_{s}=400{ }^{\circ} \mathrm{C}$, температура переходу виявляється нижчою, ніж для плівок, отриманих при $T_{s}=200{ }^{\circ} \mathrm{C}$. Проте інтенсивність переходу та гістерезис для плівок, отриманих при $T_{s}=200{ }^{\circ} \mathrm{C}$, більші, ніж при $T_{s}=400{ }^{\circ} \mathrm{C}$. Швидкість переходу для плівок $з T_{s}=200{ }^{\circ} \mathrm{C}$ і $T_{s}=400{ }^{\circ} \mathrm{C}$ була практично однаковою і становила $\approx 20{ }^{\circ} \mathrm{C}$.

\section{4. Обговорення результатів}

Отримані результати (рис. 1) показали, що параметри плівок при їх магнетронному напиленні на нагріту підкладку суттєво змінюються при незначних змінах технологічних режимів (тиску в робочій ка- мері, потужності магнетрона, температури підкладки чи концентрації кисню в суміші). Це пов'язано з тим, що зміна одного параметра технологічного процесу приводить до зміни іншого і отримати стехіометричну плівку $\mathrm{VO}_{2}$ з термохромними властивостями досить складно. Крім того, процес кристалізації протікає одночасно $з$ ростом плівки, і стимульована бомбардуванням поверхнева дифузія сприяє зародженню фази з меншим значенням зміни ентальпіі $\left(\Delta \mathrm{H}_{\mathrm{V}_{2} \mathrm{O}_{5}}=-1557\right.$ кал/моль, $\Delta \mathrm{H}_{\mathrm{VO}_{2}}=-713$ кал/моль). Зі спектрів дифракції $X$-променів на плівках оксиду ванадію, отриманих при $T_{s}=400{ }^{\circ} \mathrm{C}$, видно, що частка фази $\mathrm{VO}_{2} \in$ невеликою (рис. $4, a$ ). Плівки, вирощені в таких умовах, складаються з фаз 
$\mathrm{V}_{2} \mathrm{O}_{5}, \mathrm{VO}$, неокисленого ванадію, а також кристалітів $\mathrm{VO}_{2}$ малого розміру, які дають незначні рефлекси на дифрактограмах. Слабка інтенсивність піків діоксиду ванадію на дебаєграмі зразків, синтезованих при $T_{s}=400{ }^{\circ} \mathrm{C}$, не дає можливості оцінити середній розмір кристалітів (рис. 4,a). Зсув температури переходу в область низьких температур і велика ширина переходу зумовлені наявністю катіонів $\mathrm{V}^{3+}$, які пов'язані зі збільшенням концентрації вакансій кисню [15]. Низька інтенсивність переходу в плівках, синтезованих при $T_{s}=400{ }^{\circ} \mathrm{C}$, може бути пов'язана 3 малими розмірами кристалітів $[2,7]$. Термічний відпал цих зразків на повітрі приводить до збільшення ïх питомого опору (рис. 5), що пов'язане з окисленням включень ванадію та формуванням фази $\mathrm{V}_{2} \mathrm{O}_{5}$. Термічний відпал в атмосфері водню приводить до зменшення питомого опору плівки, що пов'язане з відновленням оксиду ванадію. Параметри переходу залишаються незмінними, що свідчить про незмінність частки включень $\mathrm{VO}_{2}$.

При температурі підкладки $200{ }^{\circ} \mathrm{C}$ осаджено аморфну плівку діоксиду ванадію, яка кристалізується під час наступних термічних обробок при температурах 300-350 ${ }^{\circ} \mathrm{C}$ (рис. 4,б). Положення піків дифракції свідчить про формування кристалітів саме діоксиду ванадію з моноклінною кристалічною граткою. Чіткі піки на дебаєграмі цих плівок дозволяють оцінити за формулою Шеррера розміри кристалітів діоксиду ванадію [2]. Така оцінка для трьох піків $(-211),(-212)$, (220) дає значення розмірів нанокристалітів $\mathrm{VO}_{2} 28$, 26 та 25 нм відповідно. Таким чином, середній розмір нанокластерів в отриманих нами плівках діоксиду ванадію становить $26 \pm 2$ нм. Отримані значення досить добре узгоджуються з літературними даними для плівок діоксиду ванадію такої ж товщини [2].

Відмінність між значеннями температури переходу $\left(T_{t}\right)$ для плівок, отриманих напиленням на підкладку з $T_{s}=400{ }^{\circ} \mathrm{C}\left(T_{t}=62{ }^{\circ} \mathrm{C}\right)$, та на підкладку, нагріту до $200{ }^{\circ} \mathrm{C}$, після додаткового відпалу $\left(T_{t}=68^{\circ} \mathrm{C}\right)$ можна пояснити більшою дефектністю кристалітів діоксиду ванадію в плівках, отриманих першим методом. У роботі [4] показано, що формування додаткових дефектів у плівках $\mathrm{VO}_{2}$ приводить до зменшення температури переходу.

Слід зазначити відмінність між значеннями температури переходу, визначеною за зміною питомого опору та оптичного пропускання для плівок, отриманих при температурі підкладки $200{ }^{\circ} \mathrm{C}$ після додаткового відпалу $\left(T_{t}=68{ }^{\circ} \mathrm{C}\right.$ та $T_{t}=55^{\circ} \mathrm{C}$ відповідно $)$. Можлива причина такої відмінності полягає у наявності в плівці нанокристалітів різного розміру, фазовий пе- рехід в яких відбувається при різних температурах. Для провідності суттєво, щоб перехід відбувся в нанокристалітах всіх розмірів, а для оптичного пропускання - тільки в тих, які складають максимальну частку у плівці. Тому, в принципі, значення температури переходу, визначені за зміною опору та оптичного пропускання, можуть відрізнятися, але це потребує подальших досліджень.

\section{5. Висновки}

Досліджено структурні, електрофізичні та оптичні властивості термохромних плівок $\mathrm{VO}_{2}$, отриманих магнетронним напиленням. Проаналізовано вплив технологічних параметрів процесу синтезу плівок оксиду ванадію на їх властивості. Дані рентгенівської дифракції підтверджують формування в синтезованих плівках кристалітів $\mathrm{VO}_{2}$ з моноклінною кристалічною граткою з середнім розміром 26 нм. Продемонстровано можливість поліпшення термохромних властивостей плівок $\mathrm{VO}_{2}$ при їх двостадійному формуванні: напиленні при температурі підкладки $200{ }^{\circ} \mathrm{C}$ i подальшим термічним відпалом. При фазовому переході в таких плівках зміна провідності досягає трьох порядків, а оптичне пропускання змінюеться (при довжині хвилі зондуючого світла $\lambda=2$ мкм) у 16 разів. Показано можливість контрольованої зміни питомого опору термохромних плівок та температури фазового переходу за рахунок термічних обробок в атмосфері кисню або водню. Запропоновано фізичні механізми впливу термічних обробок на властивості термохромних плівок діоксиду ванадію. Отримані результати пояснюються у межах моделі формування нановключень кристалічної фази $\mathrm{VO}_{2}$.

Встановлено, що температура фазового переходу для плівок, напилених на гарячу підкладку, нижча ніж для плівок, отриманих напиленням на "холодну" підкладку, після додаткової термічної обробки.

1. T. Christman, B. Felde, W. Niessner, D. Schalch, and A. Scharmann, Thin Solid Films 287, 134 (1996).

2. D. Brassard, S. Fourmax, M. Jean-Jacques, J.C. Kieffer, and M.A. El Khakani, Appl. Phys. Lett. 87, 051910 (2005).

3. F.J. Morin et al., Phys. Rev. Lett. 3, 34 (1959).

4. E.M. Heckman, L.P. Gonzalez, S. Guha, J.O. Barnes, and A. Carpenter, Thin Solid Films 518, 265 (2009).

5. H. Bialas, A. Dillenz, H. Downar, and P. Ziemann, Thin Solid Films 338, 60 (1999).

6. G. Garry, O. Durand, and A. Lordereau, Thin Solid Films 453-454, 427 (2004). 
7. R. Lopez, L.C. Feldman, and R.F. Haglund, Rev. Lett. 93, 177403 (2004).

8. H.J. Schlag and W. Scherber, Thin Solid Films 366, 28 (2000).

9. N.R. Mlyuka, G.A. Niklasson, and C.G. Granqvist, Solar Energy Materials \& Solar Cells 93, 1685 (2009).

10. S. Lu, L. Hou, and F. Gan, Thin Solid Films 353, 40 (1999).

11. Moon-Hee Lee and Myoung-Geun Kim, Thin Solid Films 286, 219 (1996).

12. A.Romanyuk, R. Steiner, L. Marot, and P. Oelhafen, Solar Energy Materials \& Solar Cells 91, 1831 (2007).

13. R.T. Kivaisi, and M. Samiji, Solar Energy Materials, \& Solar Cells 57, 141 (1999).

14. A. Gentle, A.I. Maaroof and G.B. Smith, Nanotechnology 18, 025202 (2007).

15. H. Wang, X. Yi, and Y. Li, Optics Communications 256, $305(2005)$

Одержано 25.01.11

\section{ТЕРМОХРОМНЫЕ СВОЙСТВА ПЛЕНОК ОКСИДА ВАНАДИЯ, ПОЛУЧЕННЫХ МЕТОДОМ МАГНЕТРОННОГО НАПЫЛЕНИЯ}

В.П. Мелъник, И.М. Хацевич, Ю.В. Голтвянский,

В.А. Никирин, Б.Н. Романюк, В.Г. Попов,

В.П. Кладъко, А.В. Кучук

$\mathrm{P}$ е $з$ ю м е

Исследованы структурные, электрофизические и оптические свойства термохромных пленок $\mathrm{VO}_{2}$, полученных магнетронным напылением. Продемонстрирована возможность улучшения термохромных свойств пленок $\mathrm{VO}_{2}$ при их двухстадийном формировании: напыление при температуре подложки $200{ }^{\circ} \mathrm{C}$ и последующем термическом отжиге. Данные эксперименталь- ных исследований подтверждают формирование в исследуемых пленках кристаллитов диоксида ванадия со средним размером 26 нм и моноклинной кристаллической решеткой. При фазовом переходе изменение проводимости пленок достигает трех порядков, а оптическое пропускание изменяется (при длине волны зондирующего света $\lambda=2$ мкм) в 16 раз. Показано, что изменение параметров отжига синтезированных пленок позволяет варьировать термохромные свойства пленок. Полученные результаты объясняются в рамках модели формирования кристаллитов фазы $\mathrm{VO}_{2}$.

\section{THERMOCHROMIC PROPERTIES OF VANADIUM DIOXIDE FILMS OBTAINED BY MAGNETRON SPUTTERING}

V.P. Melnik, I.M. Khatsevych, Yu.V. Goltvyanskyi, V.A. Nikirin, B.M. Romanyuk, V.G. Popov, V.P. Klad'ko, A.V. Kuchuk

V. Lashkaryov Institute of Semiconductor Physics,

Nat. Acad. of Sci. of Ukraine,

(45, Prosp. Nauky, Kyiv 03028, Ukraine;

e-mail:romb@isp.kiev.ua)

$\mathrm{S} \mathrm{u} \mathrm{m} \mathrm{m} \mathrm{a} \mathrm{r} \mathrm{y}$

The structural, electrophysical, and optical properties of thermochromic $\mathrm{VO}_{2}$ films prepared by magnetron sputtering are investigated. It is shown that the thermochromic properties of $\mathrm{VO}_{2}$ films can be improved in the case of their two-stage formation: sputtering at a substrate temperature of $200{ }^{\circ} \mathrm{C}$ followed by thermal annealing. The data of experimental studies confirm the formation of $\mathrm{VO}_{2}$ crystallites with a mean size of $26 \mathrm{~nm}$ and a monoclinic crystal lattice in the investigated films. At the phase transition, the change of the film conductivity reaches 3 orders of magnitude, while the optical transmission (at the probing light wavelength $\lambda=2 \mu \mathrm{m}$ ) changes by a factor of 16 . It is shown that the variation of annealing parameters of the synthesized films allows one to change their thermochromic properties. The obtained results are explained in the framework of the model of formation of $\mathrm{VO}_{2}$ nanoinclusions. 